Research Article

Jasmine Linnea Kelekay *

\title{
Too Dark to Support the Lions, But Light Enough for the Frontlines": Negotiating Race, Place, and Nation in Afro-Finnish Hip Hop
}

https://doi.org/10.1515/culture-2019-0033

Received August 6, 2018; accepted November 28, 2018

Abstract: In this article, I examine cultural production as an avenue for mapping African diasporic identities and racialised experiences in Finland. Hip hop culture has long acted as a lingua franca for the African diaspora and has been central in the development of collective identities among second-generation European youth of colour. Prior to the 2010s, the landscape of Finnish hip hop was largely white with little engagement with race or hip hop's roots as a Black American cultural form. This status quo was disrupted by the rise of Afro-Finnish rappers. Since gaining mainstream visibility, they have catapulted into the national consciousness with music that reclaims the language of racial and ethnic identities, interrogates assumptions about national belonging, and represents the lived experiences of first-generation Black/AfroFinnish men. Approaching hip hop as a resource for resisting normative Whiteness and carving out space for Black/African diasporic collectivities in the Finnish cultural and political imaginary, I show how AfroFinnish rappers articulate and navigate Blackness in relation to identity, racism, and national belonging in Finland. In doing so, I emphasise the tensions between racial, ethnic, and cultural hybridity, on the one hand, and the rigidity of Finnish Whiteness and national exclusion, on the other.

Keywords: Finland, Black Europe, race, music, place, hip hop, Afro-Finns

In the past decade, the fields of Black studies and African diaspora studies have increasingly expanded beyond the Americas to include the interdisciplinary study of Black communities in Europe alongside other communities of colour. As sociologist Stephen Small emphasizes, this development has been particularly important for advancing the conversation about so-called Black Europe on its own terms- to develop knowledge that is grounded in, produced by, and for the benefit of Black Europe, rather than relying on the translation of U.S.-based concepts and logic about Blackness into the European context (Small, "Introduction: The Empire Strikes Back" xxix-xxx). At the same time, research placing Black people in Europe-and especially Black citizens-at the centre within studies of race in Europe are limited, often engaging Black Europeans only to the extent that they are subcategories of other groups, such as immigrants, refugees, sex workers, criminals, or victims of sex trafficking (Small, "Theorizing Visibility and Vulnerability in Black Europe and the African Diaspora” 4).

Furthermore, although research on Black European communities have engaged questions of national belonging, racial and ethnic identity, religion, racism, and xenophobia from a range of disciplinary approaches, it has overwhelmingly focused on the histories and experiences of Black European communities within the national contexts with the largest African diasporic populations-the United Kingdom, France, the Netherlands, and Germany-while the Nordic countries remain comparatively underexplored (Blakely 4). The lack of research on the Nordic context is also attributable to the myth of "Nordic Exceptionalism,"

*Corresponding author: Jasmine Linnea Kelekay, University of California-Santa Barbara, E-mail: jasminekelekay@ucsb.edu 
which frames race as irrelevant in the Nordic countries. (Sawyer and Habel 4; McEachrane 1). Given this climate, scholarship explicitly engaging with race and racialization in Finland remains scarce, with most research instead concentrating on the language of migration and integration (Rastas, "Racializing Categorization” 148).

Cultural production represents a particularly important avenue through which to map racialised identities and experiences in Finland, as hip hop becomes one of the few public realms where questions of racialization, racism, and belonging are free to be engaged without being limited by political correctness. Hip hop music and culture are, furthermore, often considered to function as the cultural lingua franca of the African diaspora (El-Tayeb, European Others 29). Indeed, Afro-German culture scholar Fatima El-Tayeb argues that the new generation of European youth of colour and activists have "appropriated hip-hop as a tool of intervention that allows racialized communities across the continent to formulate an identity negated in dominant discourses; an identity that transcends mono-national assignments through its multiethnic and translocal frame of reference, but that nonetheless, or arguably because of it, effectively challenges minorities' expulsion from national discourses" (European Others 19).

Following El-Tayeb, I approach Afro-Finnish hip hop as a site for exploring the experiences of firstgeneration Black/Afro-Finns, analysing articulations of national, racial, and ethnic identity, as well as of national belonging and exclusion in rap songs. In order to contextualise the significance of Afro-Finnish rap as a meaningful alternative archive of the Black experience in Finland, I first introduce the Finnish context in terms of the local politics of race and racism. I then discuss the significance of hip hop music and culture for African diasporic youth, as well as its particular importance as an avenue for what bell hooks termed "talking back" from the margins (hooks 123). In my analysis, I show how Afro-Finnish rappers discuss and define Blackness in relation to identity, racism, and national belonging in Finland, emphasising the tensions between racial, ethnic, and cultural hybridity, on the one hand, and the rigidity of Finnish Whiteness and national exclusion, on the other. In this way, hip hop becomes a resource for resisting normative Whiteness and carving out space for Black/African diasporic collectivities in the Finnish cultural and political imaginary.

\section{Race and Racism in the Nordic Context}

"Nordic exceptionalism" is framed by critical scholars as the Nordic countries' investment in portraying themselves as "global 'good citizens,' peace-loving, conflict-resolution oriented and 'rational,"” including a self-conception of themselves as colour-blind bastions of equality and progressive social policy (Loftsdóttir and Jensen 2). As Afro-Swedish scholar Michael McEachrane highlights, however, this narrative relies upon the continued erasure of Nordic participation in colonialism, the transatlantic slave trade, and slavery (McEachrane 1). While none of the Nordic countries was a major colonial power, both Sweden and Denmark participated in the transatlantic slave trade and between them established colonies in the Americas, Europe, Africa, Asia, and the Atlantic (McEachrane 1-2). In the case of Finland, its history first as part of the Swedish kingdom and later as a Grand Duchy of the Russian Empire has also been used to advance what Finnish anthropologist Anna Rastas has termed "Finnish exceptionalism," by which claims to historical innocence are used to disengage with race and racism in contemporary Finnish society (Rastas, "Reading History through Finnish Exceptionalism" 90). Yet Finnish missionaries also participated in various "civilising missions" in Southern Africa, both extending a colonial hand into the continent, as well as contributing to the framing of Africa as a primitive and heathen continent in the Finnish national imaginary (Rastas, "Talking Back"). In addition to the economic gains it accrued from Swedish colonial enterprises, then, Finland has also benefitted from what social anthropologist Ulla Vuorela termed "colonial complicity" (21). ${ }^{1}$

1 It should also be noted that Finland practised "internal colonisation” in its gradual incorporation of Sápmi into its national borders, thereby displacing the indigenous Sami population from their traditional homeland (Vuorela 21). 


\section{The African Diaspora in Finland}

Unlike Britain, France, and the Netherlands, the majority of African descendants in the Nordic countries do not come from the nations' former colonies (Small, 20 Questions and Answers on Black Europe 79-80). Instead, "African descendants in the Nordic countries are...more likely shaped by the so-called "New African Diaspora' experiences of being post-colonial African immigrants." (McEachrane 6). Furthermore, most African migrants to the Nordic countries have been refugees from the Horn of Africa, which has structured both the population dynamics and the local discourses around the presence of 'racial Others.' While this population represents a great amount of cultural, ethnic, religious, and linguistic diversity, they are likely to encounter similar experiences of racialization, and, as such, experience a similar host of challenges in Finnish society (Rastas, “Talking Back” 187).

During the first half of the 1990s, Finland experienced the arrival of an unprecedented number of refugees from the Horn of Africa, surpassing all other refugee populations (Korkisaari and Söderling 8). As conflicts in East Africa calmed, the number of refugees from Africa began to settle, with the majority of recent refugees arriving from the Middle East. Today the African diaspora in Finland has diversified, including growing populations from the Democratic Republic of the Congo, Nigeria, Ethiopia, Ghana, and Morocco. Still, Somalis remain not only the largest African diasporic population in Finland but the largest non-European immigrant population, as well (Official Statistics of Finland (OSF): Population Structure). The rapid change from a society almost untouched by African immigration to a society suddenly becoming home to growing populations of Black, Brown, and Muslim people caused a backlash that journalist Esa Aallas tellingly termed "Somali Shock" (Aallas 1). Three decades later, most of the discourse about African diasporic populations in Finland remains focused on the question of integration and assimilation. Indeed, although the Black/African diasporic community has grown into its third generation, most research continues to focus on the experiences of first-generation migrants, with little engagement with the experiences of the Finnish-born second-generation.

One exception is the work of Anna Rastas, who has published articles about the experiences of African diasporic populations in Finland, including ethnic and transnational identities ("Ethnic Identities and Transnational Subjectivities"), experiences of racism (Racism in the Everyday Life of Finnish Children), and the role of music as a site for "Africanness" and diasporic cultural production (Rastas and Seye). Rastas has argued that one of the reasons why Blackness as a unifying self-identifier or a conceptual framework has yet to be embraced by most first-generation African migrants to Finland is because of their small numbers prohibiting the forming of strong collectivities ("Talking Back" 189). Another reason Rastas cites, however, is that first-generation migrants tend to maintain strong ethnic and national ties to their countries of origins, thus being less likely to adopt Blackness as their main identity, while this would likely look differently for members of the second generation, who were born or grew up in Finland ("Talking Back" 190).

If we look to the cultural realm, however, the last few years have seen the emergence of first-generation Black and Brown Finns carving out space in the national discourse (Rastas, "The Emergence of Race as a Social Category in Northern Europe”). Perhaps most notably, in 2015 Yemeni-Finnish journalist and activist Koko Hubara launched the blog RuskeatTytöt [Brown Girls], which in 2017 was expanded into the first multimedia platform for Finns of colour by Finns of colour ("Ruskeat Tytöt”). As Hubara discusses in her similarly titled 2017 collection of essays about race, racism, and the experiences of Brown girls in Finland, U.S. hip hop became almost universally embraced by the first generation of Finnish youth of colour in the 1990s, providing them with what was often the only source of both visual representations of Black and Brown bodies and discursive representations of narratives about and by members of racialized communities (Hubara 77). This speaks both to the relevance of African American cultural and political identities for the shaping of Finnish youths' understandings of Blackness, as well as to the political potential of hip hop as a cultural form. As such, I follow Black European scholars like Fatima El-Tayeb who argue that it is imperative that we look beyond state-oriented definitions of racial Others in Europe and instead centre European racial minorities' experiences, perspectives, and forms of cultural production in our inquiries (European Others xix). To do so, I approach hip hop as an alternative archive of Black/Afro-Finnish culture and experience. 


\section{Hip Hop and the African Diaspora in Europe}

Hip-hop music and culture have historically served as a tool for disrupting dominant discourses that often render racialised communities as simultaneously hyper-visible and invisible-hyper-visible in that they frequently become the subjects of discourse, but invisible in that their own narratives are excluded from such discourses (Collins 7). Indeed, since its inception in the housing projects of the Bronx in the 1970s, African American and Latino youth have used hip hop as a tool for both explicit political resistance and the creative reimagining and reclaiming of marginalised spaces (Rose, Black Noise; Rose, "Fear of a Black Planet”). As such, rap music is also an important site for examining the production of counter-discourses and -narratives. Since its global spread in the 1980s, hip hop has also been a crucial cultural sphere in which Europeans of colour have engaged the experiences of race and racism, gender, and national belonging, with scholars going as far as referring to hip hop as the lingua franca of the African diaspora (Prévos; Bennett; Morgan and Bennett; Weheliye; Lipsitz, "Diasporic Noise"; El-Tayeb, "Afro-German Activism, Gender and Hip Hop"). As Awad El Karim's work with African immigrant youth in Canada suggests, hip hop is also a tool through which African youth learn the language and contextual meaning of Blackness in predominantly white society (Ibrahim 353). Furthermore, Fatima El-Tayeb argues that hip hop has been particularly important in the development of second-generation European youth of colour identities and collectivities (European Others 11).

\section{Centering Afro-Finnish Hip Hop}

Since its arrival to Finland in the late 1980s, hip hop music and culture has, until recently, almost entirely been dominated by white Finnish men, with limited engagement with questions of cultural appropriation or discussion of its Black American roots (Kärjä). However, music scholar Antti-Ville Kärjä, for example, has analysed the prevalence of humour and parody in early Finnish rap as a strategy for managing the tensions between the racialised origins of rap music and its adoption in the Finnish context. Meri Tervo has also examined how white Finnish rappers have historically engaged in both cultural appropriation as well as the translation of elements of U.S. hip hop culture into their own localised expressions and narratives ("From Appropriation to Translation" 183). Other studies have examined the role of space and place (Tervo, "Tila Ja Paikka Suomalaisissa Räp-Musiikkivideoissa”). Although less explored, some Finnish hip hop scholars have also begun examining music produced and performed by Finnish rappers of colour, engaging how they navigate belonging (Leppänen and Westinen), being the Other (Westinen, "Multi-Semiotic Constructions of Self as Other”), and racial stereotypes (Westinen, “Who's Afraid of the Dark?”). This article contributes to this growing body of work by examining the ways in which Black/Afro-Finnish rappers discuss and define Blackness in relation to identity, racism, and national belonging in Finland.

Specifically, I discuss a selection of songs performed by James Nikander, Josijas Belayneh, Luyeye Konssi, and Hanad Hassan, better known by their rap aliases Musta Barbaari [the Black Barbarian], Prinssi Jusuf [Prince Jusuf], and the duo Seksikäs-Suklaa [Sexy Chocolate] and Dosdela, respectively. Since their arrival on the mainstream music scene in the early 2010s, Nikander, who is of Tanzanian and Finland-Swedish heritage, and Belayneh, who is of Ethiopian heritage, have catapulted into the national consciousness with music that explicitly comments on issues of identity, national belonging, and racism. While still on the margins of mainstream Finnish hip hop, they have claimed a seat at the symbolic table. Rising to the public consciousness primarily through their social media skits about life in Helsinki's eastern suburbs, Congolese-Finnish Konssi and Somali-Finnish Hassan have also translated their comedic talents into a burgeoning career as rappers. ${ }^{2}$ Although these men are not the only Black rappers in the Finnish hip hop scene, they have become particularly active media personalities, using their platforms to push forth a conversation about immigration, racism, and what it means to be Finnish.

Much like their early social media content, many of the songs intertwine social commentary with selfdeprecating humour. Indeed, the men often combine critiques of racism, national exclusion, and stereotypes

2 For the sake of clarity, I will from now on refer to the rappers discussed by their aliases. 
through plays on the very stereotypes used to caricaturize Black and African immigrants in Finland. All artists also rap in Finnish, although they often infuse Black American vernacular with Finnish urban (and specifically youth-of-colour) slang ${ }^{3}$. It should be noted that relying on translations of rap lyrics poses some analytical limitations. As a musical form that emphasises playful lyricism, rhymes, double-meanings, and layered cultural references, the analysis of rap lyrics is inherently a subjective project. Translating rap lyrics in a way that communicates both the literal meaning of words, as well as the culturally contextualised interpretations of them presents a significant added challenge. In fact, hip hop scholars have noted the complex language ideologies displayed in the rap music of African diasporic populations around the world (Pennycook; Westinen, "Multi-Semiotic Constructions of Self as Other in Finnish Rap Music Videos"; Alim; Cheeseman). Nonetheless, as a first-generation Afro-Finn myself, and as a member of the same communities as the rappers I will discuss, I aim to make use of both a systematic analytical approach and my situated lens to contextualise the lyrics I analyse within the relevant context(s).

I focus here on three particularly salient themes of national exclusion, articulations of racial and ethnic identity in resistance to erasure and racism, and the salience of place for establishing spaces of community and belonging for second-generation Finnish people of colour. The analytical themes were developed on the basis of a preliminary study of ten singles for which music videos had been made. I have chosen to explicate these themes through an in-depth analysis of the lyrics and music videos of three songs I find illustrate these themes well; Salil eka salil vika [First at the Gym Last at the Gym], Vuoden Mamu [Immigrant of the Year], and Niinku 97 [As in (19)97] ${ }^{4}$. I extend Anna Rastas' earlier work on memoirs as narratives of resistance in using bell hooks's concept of "talking back" to frame how Black/Afro-Finnish rappers similarly use hip hop culture and rap music to "talk back" to national discourses that do not acknowledge them, thus exposing the racialized mechanisms of national exclusion and the implicit boundaries of 'Finnishness.'

\title{
Racial Identity as Resistance to Racism
}

Although Nikander already had a social media following as a competitive bodybuilder, his ascent into popular culture began with the release of his first single, Salil eka salil vika [First at the Gym Last at the Gym]. The music video to the song opens with the shot of a dozen Black fists raised in the air, with a logo hovering over them; it reads "Musta Barbaari" and features a raised fist holding a dumbbell. The first words of the song declare "Still alive nigga!" As the title suggests, one of the main themes of the song is hard work. This is echoed in the chorus:

\author{
Kuka sano et saat tuloksii ilma duunii \\ Älä usko niit se on pelkkä satu \\ Musta Barbaari ei oo neekeri (nekrut ei ikin kuole) \\ Oon stadin revityin laku \\ Sä halusit saada hyötyy ilma kipuu \\ Naah nigga \\ Sun pitää olla salil eka salil vika \\ Still alive nigga \\ [Who said you could get results without doing work \\ Don't believe ‘em, it's just a fairy-tale \\ Musta Barbaari is not a nigger (niggas never die) \\ I'm the city's most ripped liquorice ${ }^{5}$ \\ You wanted to have the gain without the pain \\ Naah nigga \\ You gotta be first at the gym last at the gym \\ Still alive nigga]
}

3 For a linguistic analysis of some of Musta Barbaari and Prinssi Jusuf's songs, see (Westinen, "Still Alive, Nigga: Multi-Semiotic Constructions of Self as Other in Finnish Rap Music Videos")

4 I have translated the lyrics into English, which I will present alongside the original Finnish lyrics.

5 The Finnish slang term "stadi," although translating to "the city" is always a reference to Helsinki, the capital. 
The music video is set in a small gym, featuring Musta Barbaari rapping to the camera while other Black men lift weights in the background. In the first verse, however, the boisterous talk of working hard in the gym swiftly gets intertwined with commentary on racial stereotypes, racism, and resilience, all of which is held together with a thread of humour:

\author{
Yö on musta ja nii oon mäki \\ Joka yö kohtaan unessani Tupacin \\ Se sanoo kuuntele mua veli nyt \\ Valkoset ei ota tosissaa \\ Jos et oo revitty \\ Mä heräsin hikisenä \\ Huusin äänee still alive nigga \\ Pakko saada pumppi päälle \\ Kuolemaan asti valmis rippaa \\ Ne yrittää lähettää \\ Barbaarin takas Afrikkaa \\ Mut en oo menos bäkkii \\ Mua ei pidättele häkki \\ Liian vahva liian bläkki \\ Sun ei tarvi mua enempää motivoida \\ Mä oon paha musta mörkö \\ En oo sun kotipoika \\ Jos mun täytyy ni oon valmis salil yöpyy \\ Ei kipuu ei hyötyy, nekru häh \\ Mä käyn sossus enkä puurra hies \\ Mul on jo vaikein duuni Suomes \\ Mä oon musta mies \\ [The night is black and so am I \\ Every night in my dreams I see Tupac \\ He said brother listen up \\ Whites will never take you seriously \\ Unless you're ripped \\ I woke up in a cold sweat \\ At the top of my lungs I shouted still alive nigga \\ I gotta get a pump on \\ Prepared to tear it up until the day I die \\ They try to send \\ the Barbarian back to Africa \\ But I'm not going back \\ No cage can hold me \\ Too strong; too Black \\ I don't need any more of your motivation \\ I'm the bad Black boogie man, \\ I'm not your homeboy \\ If I have to, I'm ready to sleep at the gym \\ No pain no gain, nigga what \\ I'll collect my welfare check and not even break a sweat \\ I already have the hardest job in Finland \\ I'm a Black man]
}

In this verse, Musta Barbaari declares himself to be black as the night, using Blackness as a descriptor as well as a racial category, in contrast with his subsequent reference to "whites." The explicit deployment of the language of race, Blackness, and various uses of the n-word throughout the verse represents a clear rupture in "legitimate language" (Bourdieu 69) around the politics of difference in Finland. In a context ruled by ideologies of colour-blindness, difference is only legitimately named as a feature of immigration, culture, language, or-if you're being radical-ethnicity. By declaring himself to be Black, then, Musta 
Barbaari reclaims the language of racialization and counters the discursive erasure of Finnish people of colour. Furthermore, the varied references to Blackness throughout the verse, as well as his rap alias "the Black Barbarian" also illustrate a strategic re-appropriation of negative constructions of Black men as dangerous ("I'm the bad Black bogey man"), savage ("No cage can hold me"), and lazy (reference to welfare check), instead turning them into sources of strength.

Musta Barbaari also invokes Tupac as a source of inspiration, establishing an explicit connection to Black American hip hop and cultural figures. This also contextualises his use of language within a broader Black diasporic consciousness. The imagery of Tupac coming to him in a dream to give him advice on how to navigate racism not only represents Tupac as a transcendent cultural figure but symbolically positions African American political consciousness as a resource for Black Finnish identity and consciousness. This makes explicit the influence of Black American culture on Black/Afro-European identities and cultures. Indeed, the question of the relationship between Black America and the African diaspora inevitably arises as a central question when examining hip hop globally. While some frame the influence of hip hop culture on African diasporic communities as evidence of U.S. cultural imperialism, cultural theorist and sociologist George Lipsitz reminds us that diasporic African culture is "an ongoing dynamic creation. The radicalism [of which] comes... from the utility of exploiting diasporic connections as a way of expanding choices everywhere" (Dangerous Crossroads 39).

Furthermore, the invocation of the Black American experience as a guiding force in the struggle against racism in Finland is an example of what Lipsitz refers to as "strategic anti-essentialism," which "gives the appearance of celebrating the fluidity of identities, but in reality seeks a particular disguise on the basis of its ability to highlight, underscore, and augment an aspect of one's identity that one can not express directly" (Lipsitz, Dangerous Crossroads 62). In other words, although Blackness entails different meanings, experiences, and histories in the Finnish context than it does in the United States, the strategic alliance with African American discourse allows for the deployment of an explicit critique of racism that may otherwise be deemed contextually irrelevant. Indeed, the racism Musta Barbaari refers to in this verse spans the interpersonal ("Whites will never take you seriously unless you're ripped"), the institutional, both in terms of labour ("I already have the hardest job in Finland, I'm a Black man") and migration ("they try to send the Barbarian back to Africa"), and the cultural ("I'm not your homeboy").

In addition to his stage name being called too on-the-nose and confusing, it was his use of the n-word, the explicitly racialised language, and the claim that being a Black man was the "hardest job in Finland" that sparked the most controversy (Poikelus). Musta Barbaari was interviewed for numerous articles where he was asked to explain his choice of language, as well as his claims about life in Finland. For example, one article published by the Finnish national broadcasting network declared "Musta Barbaari provokes with lyrics riddled with the word nigger" (Vedenpää). Much of the media discourse followed similar lines, along with social media discussions admonishing him for the perceived inappropriateness of his lyrics. His discussion of race and racial stereotypes was also accused of being racist and of increasing rather than decreasing prejudices. While controversial, the song also received overwhelming praise, with young people of colour applauding Musta Barbaari for finally giving voice to the experiences of immigrant youth and, in doing so, carving out a space for them in the national culture.

\section{Resisting National Exclusion}

Another aspect of everyday experiences of racism that Afro-Finnish rappers highlight is what they frame as the selective and strategic (if not exploitative) politics of national exclusion. This dynamic is perhaps most explicit in Prinssi Jusuf and Musta Barbaari's song Vuoden Mamu [Immigrant of the Year], in which they discuss being framed as perpetual foreigners unable to partake in Finnish society and culture, all the while being expected to perform their civic duties as Finnish citizens, such as paying taxes and serving in the Finnish army. Indeed, the very title of the song is suggestive of a national discourse that divides people into categories of 'good' and 'bad' immigrants. Released in 2016, it is noteworthy that Vuoden Mamu also came out in the aftermath of Belayneh (Prinssi Jusuf) receiving a great deal of publicity during the summer of 2015 
for saving a woman's life when he pulled her out after falling onto the subway tracks. The media lauded him as a hero, and he even received a medal from Finnish President Niinistö (Ampuja). It is fitting, then, that the next single he released explored the tensions inherent in such celebrations of "good immigrants." The lyrics of the song play with the stereotypical immigrant values of hard work and the pressures and negative stereotypes imposed by a society that requires such narratives in the first place:

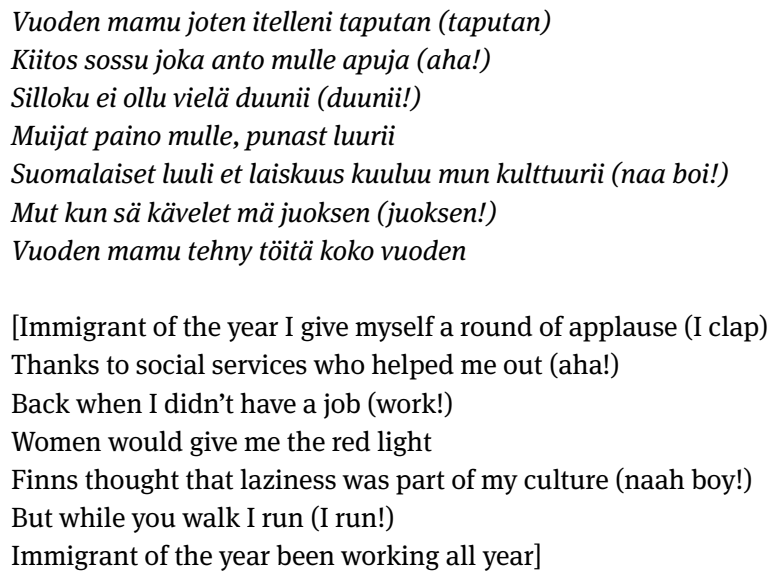

In this verse, we see an explicit reference to "Finns" assuming the familiar stereotype that laziness is part of Black/African culture. By constructing Finns as external to him, and as people who do not share this stigmatised culture, we can understand racial stereotypes to function as a mechanism of exclusion, which in turn affirms the association between Finnishness and Whiteness. The stereotype is then contradicted in the line that follows ("But while you walk, I run") referencing the pressure of immigrants having to work harder than Finns to be successful in Finnish society (and to counter the stereotype of laziness). The second part of the first verse also adds commentary on racism and ethnonationalism in Finnish politics:

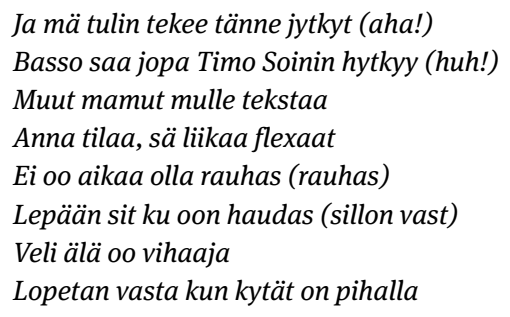

[And I came here to blow it up (aha!)

The bass will even have Timo Soini getting down

Other immigrants text me

Make some space, you're flexing too much ${ }^{6}$

No time to be at peace (at peace)

I'll rest when I'm in the grave (not 'til then)

Brother don't be a hater

I won't stop until the cops are outside!]

What I have translated as the line "blow it up," in the original Finnish used the word jytkyt, which is associated with Perussuomalaiset [Finns Party] co-founder and current Minister of Foreign Affairs, Timo Soini, who is credited with inventing the term, in reference to the right-wing and anti-immigrant party's unprecedented success in the 2011 parliamentary elections (Tamminen). Coupled with reference to Timo Soini in the next line, we see Prinssi Jusuf's appropriation of the word jytkyt as something used to

6 "Flexing too much" is a reference to showing off or bragging. 
reference the explosive rise of right-wing populism to something that describes the explosive power of his music-which, he adds, will be irresistible even to Soini. We see another linguistic appropriation in the use of the Finnish slang word mamu in reference to immigrants. The actual Finnish word for immigrant is the much longer maahanmuuttaja, which is often associated with negative discourses. What immigrant communities have done, however, is re-claim this term in its vernacular version ("mamu") in references to themselves, thereby turning a label used by mainstream discourses to externalize people of colour from Finland (El-Tayeb, European Others: Queering Ethnicity in Postnational Europe xxi) into a label of collective identification.

The second verse, performed by Musta Barbaari, also reaffirms the notion that immigrants have to work twice as hard, and explicitly makes the connection between race and national exclusion:

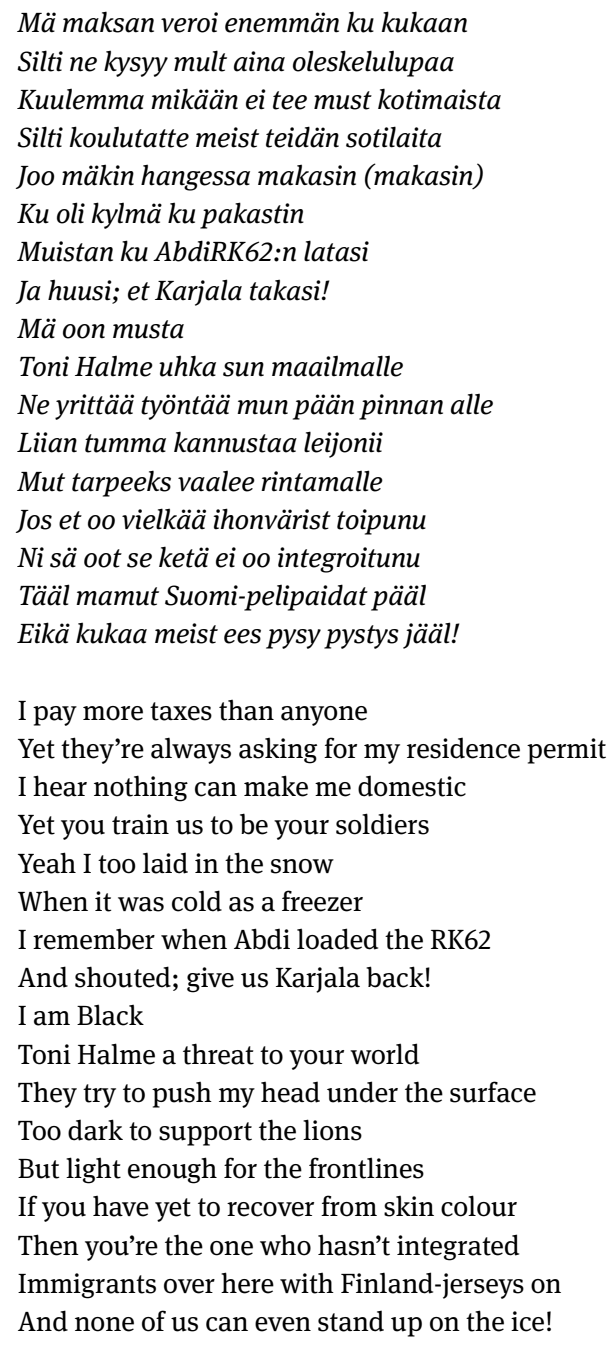

This verse exposes the tensions between being a citizen and a contributing member of Finnish society, all the while constantly having the legitimacy of one's presence in the country questioned. It also highlights the contradiction inherent in constructing immigrants and people of colour as perpetually foreign, while legally requiring that all young men-including (naturalised) immigrant men of colour-serve in the nation's armed forces. As he states, these men, too, endured the national masculine coming-of-age ritual by suffering through boot camp during the harsh Finnish winter. In fact, as Musta Barbaari suggests, these men, too, have adopted the national narrative about the tragic loss of the eastern region of Karelia to the Soviet Union in the Moscow Treaty of 1940, a sacrifice made to preserve newly-gained Finnish national sovereignty, but resulting in the displacement of nearly 500,000 Finns (Kirby 215). The reference to the Arabic name "Abdi" signals that the soldier loading the RK62-an assault rifle that is standard issue in 
the Finnish defence forces-is Muslim and (likely) Somali. That he is demanding the return of Karjala demonstrates Abdi's marking of himself as a part of the Finnish nation that once lost it-even though his family would not yet have been here.

The second part of the verse makes reference to another element of national exclusion in the form of exclusion from participation in an important element of national culture: sports. When he says, "too dark to support the lions; but light enough for the frontlines," he is referencing the Finnish national hockey team known as the lions of Finland. Not insignificantly, the name of the Finnish national team is a reference to the lion in the Finnish coat of arms. Here again, a form of exclusion is juxtaposed against the strategic inclusion of people of colour when it is that their inclusion will serve the purpose of defending the country's borders. There is also an inherent irony pointed out here in that being called to serve in protection of Finland's borders, and thus Finnish national sovereignty, is so starkly contrasted with the internal boundaries drawn around Finnish national belonging. Indeed, Musta Barbaari ends the verse with reference to the tendency of national discourses to frame immigrants-and Black immigrants, in particular-as fundamentally inassimilable. In response, Musta Barbaari claims that "if you have yet to recover from skin colour, you are the one who hasn't integrated.” In addition to framing racism as an ailment, the statement accomplishes two additional things: it explicitly defines claims about challenges to integration as racialised, rather than a matter of immigration or culture, and by doing so, it also disrupts the illusion that Finnish national discourses about immigration are colour-blind.

In the music video, Prinssi Jusuf and Musta Barbaari are both wearing the Finnish national ice hockey team's jerseys-a potentially small and uncontroversial gesture, but which in the Finnish context cuts to the core of questions about national culture and representation. Like many of its neighbouring countries, ice hockey is considered Finland's national sport, and a source of national pride, especially when playing against arch-rivals Sweden or Russia. At the national level, ice hockey also remains an exclusively "white" sport, thus remaining relatively untouched by debates about whether athletes of colour can adequately represent Finland on the international stage. The last line again illustrates the dedication of immigrants to adopt Finnish national narratives and culture. Indeed, he comically exclaims, "immigrants over here with Finland-jerseys on; and none of us can even stand up on the ice!” With this statement, Musta Barbaari points out the complicated entwining of sports and national pride in the symbolic significance of the national jersey. This is affirmed by his suggestion that immigrants wear the jersey not for the love of the sport (since he says they cannot even ice skate), but rather as a way to participate in Finnish national culture.

\section{Race, Space, and Belonging}

In contrast to the discourses of national exclusion, Afro-Finnish rappers highlight the importance of urban space and especially marginalised immigrant-dense neighbourhoods as spaces of belonging. In nearly all songs, references are made to the eastern suburban district of Helsinki, which is considered the primary home of African immigrants in Finland, and where all the men themselves grew up. As is the case in other European countries, the majority of Black/African diasporic populations reside in greater metropolitan areas (Small, 20 Questions and Answers on Black Europe 77). Immigrants have also historically tended to reside in particular parts of Helsinki, with East Helsinki neighbourhoods being home to the greatest immigrant populations. For example, in 2016, over thirty-four per cent of the East Helsinki neighbourhood of Meri-Rastila's population was of foreign descent (Malmberg). East Helsinki is also colloquially considered to be the main home of Black communities in Helsinki, as suggested by common references connecting East Helsinki to immigrants in hip hop culture as well as television programs. One of the most notable examples includes the short-lived television series dealing with the everyday lives of immigrants in East Helsinki entitled Mogadishu Avenue, a reference to the nickname of the main street in the Meri-Rastila neighbourhood where many Somalis live (Ahola).

In several songs by Afro-Finnish rappers, East Helsinki is discussed as a space of belonging, home, and freedom (juxtaposed against the broader context of exclusion), as well as in terms of its reputation as home to immigrants and low-income residents. The first single released by Seksikäs-Suklaa and Dosdela, Niinku 97 [As in (19)97], perhaps serves as the most explicit example. 


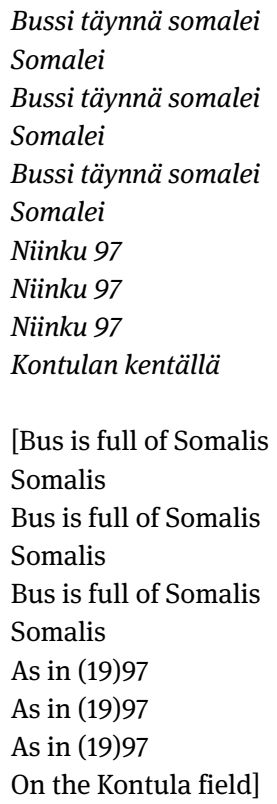

The title "As in (19)97," in combination with the reference to the Kontula field, invokes the infamous 1997 attack in which a group of Nazis assaulted Somali youngsters playing football on a field-an attack which reverberated throughout Finland's Black communities and has since become an urban legend (Sarhimaa). The music video to the song features a bus full of young Black passengers-including many other Black/ Afro-Finnish rappers-driving around in circles on this field as they dance along to the trap beats of the song. The seriousness of the racial violence referenced, thus, is juxtaposed against this celebratory image of the community.

The title's use of "97" also gestures toward a layered reference to the postal code (00970) and corresponding bus line (97), which runs through the East Helsinki neighbourhoods of Kontula and Mellunmäki. The use of the bus-a racialized and classed public space in its own right-to represent the social dynamics of the broader community is not only relevant to the extent that it serves as a marker of who may be represented as passengers on a given bus line, but it also speaks to local common-sense understandings of what George Lipsitz refers to as the racialization of space and the spatialization of race ("The Racialization of Space" 12). Indeed, bus lines in Helsinki are overwhelmingly (although not exclusively) numbered according to the postal codes they serve in the northern and eastern working-class suburbs, thus symbolically marking bus lines as extensions of the communities they serve. The bus line someone takes, then, serves as a colloquial signifier of the community they are from. From this perspective, the staging of the 97 bus as a Black social sphere is not that unusual.

It is also illustrative of the tongue-in-cheek spirit of the song, as exemplified by the first verse's commentary on going 'clubbing' as an illustration of classed differences:

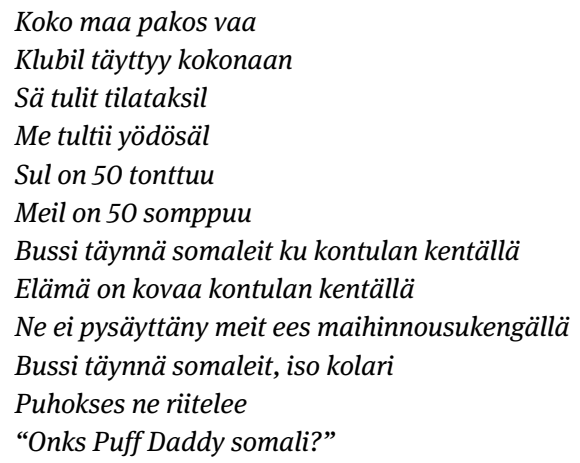


[The whole country escaping

The club fills up completely

You came with a pre-ordered cab

We took the night bus

You got 50 acres

We got 50 Somalis

Buss full of Somalis like the Kontula field

Life is rough on the Kontula field

They didn't even stop us with combat boots

Bus is filled with Somalis, big accident

At Puhos they're arguing

“Is Puff Daddy Somali?”]

The image of leisure is again juxtaposed against the "rough life" of Kontula. With another reference to the '97 attack, this verse also asserts resilience in the face of militant racism ("they didn't even stop us with combat boots.") Indeed, the music video continues to show the young passengers of the bus getting out onto the field and enjoying an impromptu block party complete with games, dancing, and barbequing. The juxtaposition of the field as a symbolic site of the struggles of Black communities in Finland against images of celebration, then, signals a deliberate reclaiming of embattled public space. The mention of "Puhos" is a reference to an old shopping centre in East Helsinki where the majority of shops are immigrant-owned. A staple in the community, Puhos features halal butchers, a Turkish market, a Somali café, and a mosque space, for example. The song's reading as an ode to east Helsinki as a Black/African diasporic space is made explicit in the second verse, as they call out various eastern neighbourhoods:

Tää lähtee kaikille kontulast

Itiksest, vuosaarest mis vaan on somppuja

[This goes out to everyone from Kontula

From Itis, Vuosaari, wherever there are Somalis]

These creative re-imaginings of marginalised spaces as spheres of community and belonging represent a core feature of Black community-making in the African diaspora, as well as a central component of hip hop culture (Forman; Lipsitz, Dangerous Crossroads; Rose).

\section{Discussion}

I have highlighted three related ways in which first-generation Black/Afro-Finnish rappers use hip hop to negotiate racialised lived experiences; by resisting national exclusion, articulating and affirming racialised identities in resistance to colour-blind racism, and by reclaiming marginalised places as a way to carve out spaces of belonging within the physical landscape of the nation. In advancing these discourses, I argue, these rappers have also claimed their place in the cultural imaginary. In this way, hip hop becomes not only an avenue for the articulation of racialised lived experiences in Finnish society but a means of conjuring new meanings of what it is to be Finnish (Westinen, "Multi-Semiotic Constructions of Self as Other in Finnish Rap Music Videos"; Leppänen and Westinen). By approaching hip hop as a living archive and as a site for the production of counter-narratives that "talk back" to mainstream colour-blind discourses, this study contributes to both Finnish and global studies of hip hop, understandings of the politics of race and racism in Finland, and the expanding study of Black European identities and cultures.

A consistent feature of how Afro-Finnish rappers engage identity is the fluidity of the language which rappers use to refer to themselves and their experiences in racialised, ethnic, and national terms. These rappers often use explicitly racialised language by referring to themselves as Black, while in other moments aligning themselves with the categories of Finn, immigrant, African, and, in some cases, with specific African national identities, such as Somali or Ethiopian. As such, all rappers appear to use racial, ethnic, and national language in fluid ways, suggesting both the salience of these social categories for their everyday 
lives, but also the hybridity of these identities. This complex combination of racial, ethnic, and national identities also suggests the importance of advancing intersectional readings of their use of language, as Blackness, Africanness, and foreignness are entwined in the Finnish national imagination. Hybridity in both modes of identification and expression appears to be a defining feature of African diasporic hip hop around the globe. The use of hybrid language, for example, is a common way in which rappers navigate between hip hop's origins as a Black American cultural form, the global elements of hip hop culture, and its localized manifestations (Alim; Bennett, "Hip Hop Am Main: The Localization of Rap Music and Hip Hop Culture"; Androutsopoulos and Scholz; Droessler; Pennycook).

While the rappers discussed here exercise their agency in strategically invoking different identities, they also distinguish themselves and their experiences from that of "Finns," thus framing themselves outside of the boundaries of Finnishness, tacitly suggesting that Finnishness continues to at least in part be defined by Whiteness. This speaks to the continued salience of the construction of people of colour as external to the Finnish nation and the persistence with which second-generation Finnish people of colour continue to be excluded from the society they know as home. This dynamic becomes particularly salient in songs that include commentary on what they frame as the selective and strategic (if not exploitative) dynamic of national inclusion, such as being framed as perpetual foreigners unable to partake in Finnish culture, all the while being required to perform their duties as Finnish citizens. The construction of secondgeneration people of colour as perpetual foreigners without a legitimate claim to the nation is also a persistent aspect of European racial politics-even in national contexts where people of colour have been part of the national landscape since the colonial era (El-Tayeb, European Others; Alba; Hine et al.). Indeed, while the construction of Finnishness as reliant on Whiteness is in part rooted in the notion that Finland has historically been ethnically homogenous (Tervonen), the mutual entwining of race and nation is also a legacy of colonial boundary-making to ensure the "externalization" of the racial Other even within the nation (Balibar and Wallerstein 39-45).

Hip hop scholars have also emphasized the importance of race and place in hip hop, both in the United States and globally (Forman, “Represent”; Rose; Forman, “Ain’t No Love in the Heart of the City”; Hebdige; Bennett, "Hip-Hop Am Main, Rapping' on the Tyne"). As Murray Forman has argued, hip hop is not only intimately tied to the politics of place by virtue of its birth in the context of post-industrial urban America (Black Noise 21), but also because of the centrality of neighbourhood, city-based, and regional identities throughout hip hop history ("Ain't No Love in the Heart of the City: Hip-Hop, Space, and Place" 203-06). The globalization of hip hop culture, then, has led rappers around the world to navigate between cultural appropriation, on the one hand, and the translation of U.S. hip hop to their local contexts, on the other (Tervo, "From Appropriation to Translation"; Androutsopoulos and Scholz; Bennett, "Hip Hop Am Main: The Localization of Rap Music and Hip Hop Culture"; Ramsdell). In the African diaspora, the spread of hip hop has also rendered U.S. Blackness accessible as a resource for establishing transnational as well as local identities (Ibrahim; El-Tayeb, Afro-German Activism, “Gender and Hip Hop”). The use of U.S. Blackness as a resource for navigating the local politics of race is highlighted by the Afro-Finnish rappers I discuss in their incorporation of African American Vernacular English (AAVE), as well as the invoking of politically conscious Black American rapper, Tupac, as a guide for how to navigate racism in Finnish society.

The hybridization of racial, ethnic, continental, and national identities appears to be central not only to the Afro-Finnish experience but rather speaks to the complex politics of identity in the so-called 'new African diaspora,' as well as what Fatima El-Tayeb describes as the "queering of ethnicity" in the diverse, migrant-dense, urban communities in Europe. Yet the salience of race as a marker of national exclusion also speaks to the precarious social status of second- and third-generation people of colour in Europe. The embrace of hip hop by first-generation Finnish youth of colour, then, reflects not only the global appeal of U.S. hip hop culture but also the importance of US Blackness as a political and cultural resource for the emerging Black diaspora in Finland. The centrality of East Helsinki in emerging Afro-Finnish rap illustrates the reclaiming and reimagining of marginalized social space that is a staple of hip hop culture, representing one of the central ways in which Black/Afro-Finnish youth use hip hop as a resource for advancing a politic of belonging in a context that continues to frame them as the Other. 


\section{Works Cited}

Aallas, Esa. Somalishokki [Somali shock]. Suomen pakolaisapu, 1991.

Ahola, Merituuli. “Cultural Diversity on 'Mogadishu Avenue' in Helsinki.” Hiiraan Online, http://www.hiiraan.com/ news4/2006/nov/345/cultural_diversity_on_mogadishu_avenue_in_helsinki.aspx. Accessed 6 Aug. 2018.

Alba, Richard. "Bright vs. Blurred Boundaries: Second-Generation Assimilation and Exclusion in France, Germany, and the United States." Ethnic and Racial Studies, vol. 28, no. 1, Jan. 2005, pp. 20-49, doi:10.1080/0141987042000280003.

Alim, H. Samy. "Translocal Style Communities: Hip Hop Youth as Cultural Theorists of Style, Language, and Globalization." Pragmatics, vol. 19, no. 1, Mar. 2009, pp. 103-27, doi:10.1075/prag.19.1.06ali.

Ampuja, Eetu. “Prinssi Jusuf Pelasti Naisen Varmalta Kuolemalta Metrossa - Saa Presidentti Niinistöltä Hengenpelastusmitalin. [Prinssi Jusuf Saved Woman from Certain Death in the Metro - Receives Life Saving Medal from President Niinistö]." Ilta-Sanomat, 3 June 2016, https://www.is.fi/viihde/art-2000001193594.html.

Androutsopoulos, Jannis, and Arno Scholz. "Spaghetti Funk: Appropriations of Hip-Hop Culture and Rap Music in Europe." Popular Music and Society, vol. 26, no. 4, Dec. 2003, pp. 463-79, doi:10.1080/0300776032000144922.

Balibar, Etienne, and Immanuel Maurice Wallerstein. Race, Nation, Class: Ambiguous Identities. Verso, 1991.

Bennett, Andy. “Hip Hop Am Main: The Localization of Rap Music and Hip Hop Culture.” Media, Culture \& Society, vol. 21, no. 1, 1999, pp. 77-91.

--.. “Hip-Hop Am Main, Rapping' on the Tyne: Hip-Hop Culture as a Local Construct in Two European Cities.” That's the Joint!: The Hip Hop Studies Reader, edited by Mark Anthony Neal and Murray Forman, Routledge, Taylor \& Francis Group, 2004, pp. 177-201.

Blakely, Allison. “The Emergence of Afro-Europe: A Preliminary Sketch.” Black Europe and the African Diaspora, edited by Darlene Clark Hine et al., University of Illinois Press, 2009, pp. 3-28.

Bourdieu, Pierre. Language and Symbolic Power. Harvard University Press, 1991.

Cheeseman, Tom. "Polyglot Politics. Hip Hop in Germany.” Debatte: Journal of Contemporary Central and Eastern Europe, vol. 6, no. 2, Nov. 1998, pp. 191-214, doi:10.1080/09651569808454589.

Collins, Patricia Hill. From Black Power to Hip Hop: Racism, Nationalism, and Feminism. Temple University Press, 2006.

Droessler, Holger. "From A-Town to ATL: The Politics of Translation in Global Hip Hop Culture." The Journal of Hip Hop Studies, vol. 2, no. 1, 2015, pp. 100-16.

El-Tayeb, Fatima. European Others: Queering Ethnicity in Postnational Europe. University of Minnesota Press, 2011.

--.. “If You Can’t Pronounce My Name, You Can Just Call Me Pride’: Afro-German Activism, Gender and Hip Hop.” Gender \& History, vol. 15, no. 3, 2003, pp. 460-486.

Forman, Murray. “Ain't No Love in the Heart of the City: Hip-Hop, Space, and Place.” That's the Joint!: The Hip-Hop Studies Reader, edited by Mark Anthony Neal and Murray Forman, Routledge, Taylor \& Francis Group, 2004, pp. 155-158.

-.-. “'Represent': Race, Space and Place in Rap Music.” Popular Music, vol. 19, no. 1, 2000, pp. 65-90.

Hebdige, Dick. "Rap and Hip-Hop: The New York Connection.” That's the Joint!: The Hip-Hop Studies Reader, edited by Mark Anthony Neal and Murray Forman, Routledge, Taylor \& Francis Group, 2004, pp. 223-33.

Hine, Darlene Clark, et al., editors. Black Europe and the African Diaspora. University of Illinois Press, 2009.

hooks, bell. "Talking Back." Discourse, vol. 8, no. She, The Inappropriate/D Other, 1986, pp. 123-28.

Hubara, Koko. Ruskeat Tytöt: Tunne-Esseitä [Brown Girls: Personal Essays]. Like Kustannus OY, 2017.

Ibrahim, Awad El Karim M. "Becoming Black: Rap and Hip-Hop, Race, Gender, Identity, and the Politics of ESL Learning." TESOL Quarterly, vol. 33, no. 3, 1999, pp. 349-69. JSTOR, doi:10.2307/3587669.

Kärjä, Antti-Ville. “Ridiculing Rap, Funlandizing Finns? Humour and Parody as Strategies of Securing the Ethnic Other in Popular Music." Migrating Music, edited by Jason Toynbee and Byron Dueck, Routledge, 2011, pp. 94-107.

Kirby, David. A Concise History of Finland. Cambridge University Press, 2006.

Korkisaari, Jouni, and Ismo Söderling. Finnish Emigration and Immigration after World War II. Migration Institute, 2003.

Leppänen, Sirpa, and Elina Westinen. "Migrant Rap in the Periphery: Performing Politics of Belonging." AILA Review, vol. 30 , Jan. 2018, pp. 1-26, doi:10.1075/aila.00001.lep.

Lipsitz, George. Dangerous Crossroads: Popular Music, Postmodernism and the Poetics of Place. Verso, 1994.

---. “Diasporic Noise: History, Hip Hop, and the Post-Colonial Politics of Sound." Popular Culture: Production and Consumption, 1994, pp. 180-200.

--. "The Racialization of Space and the Spatialization of Race: Theorizing the Hidden Architecture of Landscape." Landscape Journal, vol. 26, no. 1, 2007, pp. 10-23.

Loftsdóttir, Kristín, and Lars Jensen. Whiteness and Postcolonialism in the Nordic Region: Exceptionalism, Migrant Others and National Identities. Routledge, 2016.

Malmberg, Lari. “Helsingin Meri-Rastilan asukkaista 34 prosenttia on maahanmuuttajataustaisia -Vuokratalojen valtaamaan kaupunginosaan yritetään houkutella omistusasujia. [34 percent of residents of Helsinki's Meri-Rastila are of foreign background - homeowners are enticed to the district filled with apartment rentals]." Helsingin Sanomat, 26 Feb. 2017, https://www.hs.fi/kaupunki/art-2000005103735.html?share=fa92031982db03e37177689b8fcc0f9f.

McEachrane, Michael. Afro-Nordic Landscapes: Equality and Race in Northern Europe. Routledge, 2014. 
Morgan, Marcyliena, and Dionne Bennett. “Hip-Hop \& the Global Imprint of a Black Cultural Form.” Daedalus, vol. 140, no. 2, 2011, pp. 176-196.

Official Statistics of Finland (OSF): Population Structure. e-publication, Statistics Finland, http://www.stat.fi/til/vaerak/index_ en.html. Accessed 15 Nov. 2018.

Pennycook, Alastair. "Language, Localization, and the Real: Hip-Hop and the Global Spread of Authenticity." Journal of Language, Identity \& Education, vol. 6, no. 2, June 2007, pp. 101-15, doi:10.1080/15348450701341246.

Poikelus, Jenni. “Musta Barbaari haluaa rikkoa ennakkoluuloja. [Musta Barbaari wants to shatter stereotypes]." YLEX, 28 Aug. 2013, http://yle.fi/aihe/artikkeli/2013/08/28/musta-barbaari-haluaa-rikkoa-ennakkoluuloja.

Prévos, André JM. "The Evolution of French Rap Music and Hip Hop Culture in the 1980s and 1990s." French Review, 1996, pp. 713-725.

Ramsdell, Lea. “Cuban Hip-Hop Goes Global: Orishas’ A Lo Cubano.” Latin American Music Review / Revista de Música Latinoamericana, vol. 33, no. 1, 2012, pp. 102-23.

Rastas, Anna. "Ethnic Identities and Transnational Subjectivities." Multiple Identities: Migrants, Ethnicity, and Membership, edited by Paul Spickard, Indiana University Press, 2013, pp. 41-60.

--.. "Racializing Categorization among Young People in Finland." Young, vol. 13, no. 2, 2005, pp. 147-166.

--.. "Racism in the Everyday Life of Finnish Children with Transnational Roots." Barn, vol. 19, no. 1, 2009, pp. 29-43.

-.-. "Reading History through Finnish Exceptionalism." Whiteness and Postcolonialism in the Nordic Region, edited by Kristín Loftsdóttir and Lars Jensen, Routledge, 2016, pp. 101-116.

--.. "Talking Back: Voices From the African Diaspora in Finland." Afro-Nordic Landscapes: Equality and Race in Northern Europe, edited by Michael McEachrane, Routledge, 2014, pp. 187-207.

--.. "The Emergence of Race as a Social Category in Northern Europe." Relating Worlds of Racism: Dehumanisation, Belonging, and the Normativity of European Whiteness, edited by Philomena Essed et al., Palgrave Macmillan, 2019, pp. 357-381.

Rastas, Anna, and Elina Seye. "Music as a Site for Africanness and Diaspora Cultures: African Musicians in the White Landscape of Finland." African and Black Diaspora: An International Journal, vol. 9, no. 1, Jan. 2016, pp. 82-95. Crossref, doi:10.1080/17528631.2015.1055652.

Rose, Tricia. Black Noise: Rap Music and Black Culture in Contemporary America. Wesleyan University Press, 1994.

-.-. “'Fear of a Black Planet': Rap Music and Black Cultural Politics in the 1990s.” The Journal of Negro Education, vol. 60, no. 3, 1991, pp. 276-90, doi:10.2307/2295482.

“Ruskeat Tytöt [Brown Girls].” Ruskeat Tytöt, https://www.ruskeattytot.fi/. Accessed 19 Nov. 2018.

Sarhimaa, Jutta. "Skinit hyökkäsivät somalien kimppuun, siitä kasvoi somalisukupolven urbaanilegenda, ja nämä koomikot tekivät tappelusta voimabiisin. [Skinheads attacked Somalis, it developed into a Somali generation's urban legend, and these comedians turned the fight into a power song]." Helsingin Sanomat, 9 May 2016, https://www.hs.fi/nyt/

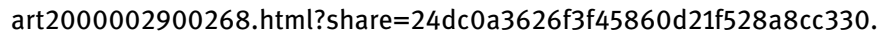

Sawyer, Lena, and Ylva Habel. "Refracting African and Black Diaspora through the Nordic Region." African and Black Diaspora: An International Journal, vol. 7, no. 1, 2014, pp. 1-6, doi:10.1080/17528631.2013.861235.

Small, Stephen. 20 Questions and Answers on Black Europe. Amrit Publishers, 2018.

--.. "Introduction: The Empire Strikes Back." Black Europe and the African Diaspora, edited by Darlene Clark Hine et al., University of Illinois Press, 2009, pp. xxiii-xxxviii.

--.. "Theorizing Visibility and Vulnerability in Black Europe and the African Diaspora." Ethnic and Racial Studies, vol. 41, no. 6, 2018, pp. 1182-97, doi:10.1080/01419870.2018.1417619.

Tamminen, Jenni. "Timo Soini ja "jytky"-Sanan alkuperä paljastui” [Timo Soini and "jytky" - the word's origins revealed]. Uusi Suomi, 18 Apr. 2011, https://www.uusisuomi.fi/kotimaa/111375-timo-soini-ja-\%E2\%80\%9Djytky\%E2\%80\%9D\%E2\%80\%93-sanan-alkupera-paljastui.

Tervo, Mervi. “From Appropriation to Translation: Localizing Rap Music to Finland.” Popular Music and Society, vol. 37, no. 2, Mar. 2014, pp. 169-86. Crossref, doi:10.1080/03007766.2012.740819.

--.. “Tila Ja Paikka Suomalaisissa Räp-Musiikkivideoissa. [Space and Place in Finnish Rap-Music Videos].” Alue Ja Ympäristö, vol. 41, no. 2, 2012, pp. 81-94.

Tervonen, Miika. "Historiankirjoitus Ja Myytti Yhden Kulttuurin Suomesta. [Writing History and the Myth of a Monocultural Finland]." Kotiseutu Ja Kansakunta: Miten Suomalaista Historiaa on Rakennettu, edited by Pirjo Markkola et al., Suomen Kirjallisuuden Seura, 2014, pp. 137-162.

Vedenpää, Ville. “Musta Barbaari provosoi neekeri-sanaa viljelevillä sanoituksillaan [Musta Barbaari provokes with lyrics filled with the word nigger]." Yle Uutiset, 7 Sept. 2013, http://yle.fi/uutiset/musta_barbaari_provosoi_neekeri-sanaa_ viljelevilla_sanoituksillaan/6814872.

Vuorela, Ulla. “Colonial Complicity: The 'Postcolonial' in a Nordic Context.” Complying with Colonialism: Gender, Race and Ethnicity in the Nordic Region, edited by Suvi Keskinen et al., Routledge, 2016, pp. 31-46.

Weheliye, Alexander G. “My Volk to Come: Peoplehood in Recent Diaspora Discourse and Afro-German Popular Music." Black Europe and the African Diaspora, edited by Darlene Clark Hine et al., University of Illinois Press, 2009, pp. 161-79.

Westinen, Elina. “'Still Alive, Nigga': Multi-Semiotic Constructions of Self as Other in Finnish Rap Music Videos.” Social Media Discourse, (Dis)Identifications and Diversities, edited by Sirpa Leppänen et al., Routledge, 2017, pp. 335-60. 
--.. “'Who's Afraid of the Dark?': The Ironic Self-Stereotype of the Ethnic Other in Finnish Rap Music.” The Sociolinguistics of Hip-Hop as Critical Conscience: Dissatisfaction and Dissent, edited by Andrew S. Ross and Damian J. Rivers, Springer International Publishing, 2018, pp. 131-61, doi:10.1007/978-3-319-59244-2_6. 